\title{
Migrant values and social remittances across the contemporary migration-development nexus: the case of Moldovans in Czechia
}

\author{
DUŠAN DRBOHLAV ${ }^{1}$, ADRIAN BAILEY ${ }^{2}$, MILAN LUPTÁK $^{1}$, DITA ČERMÁKOVÁ ${ }^{1}$
}

\footnotetext{
${ }^{1}$ Charles University, Faculty of Science, Department of Social Geography and Regional Development, Prague, Czechia; e-mail: dusan.drbohlav@natur.cuni.cz, luptakm@seznam.cz, dita. cermakova@natur.cuni.cz

${ }^{2}$ Hong Kong Baptist University, Faculty of Social Sciences, Department of Geography, Hong Kong; e-mail: bailey@hkbu.edu.hk
}

ABSTRACT Migration theory and international policy recognises that migrant remittances play significant roles in shaping economic, social, and political transformations in origins and destinations. However, nobody deals with how migrants experience and use values. To contribute to the development of migration theory we integrate insights from modernization, social remittance, and cleavage frameworks. We test three propositions, that values are experienced in comparative and relational ways, that values are selectively transferred in context specific ways, and that values are constitutive of social and economic structures. Our original empirical account is derived from a sample of 28 Moldovan migrants living and working in Czechia. We report three main findings, first, Moldovan migrants acquire values through a process of relating them to prior experiences in their daily life in their origin; second, social remittances appear, but to limited extent, and are transferred depending on the operation of cleavages in Moldovan society; third, values respond to and reinforce corruption and low market demand in Moldova, and may perpetuate over the medium term owner/worker and government/society cleavages in Moldovan society.

KEY WORDS social remittances - human values - migration - migration-development nexus interviews - Moldova - Czechia

DRBOHLAV, D., BAILEY, A., LUPTÁK, M., ČERMÁKOVÁ, D. (2017): Migrant values and social remittances across the contemporary migration-development nexus: the case of Moldovans in Czechia. Geografie, 122, 4, 526-553.

Received October 2017, accepted November 2017.

CC Česká geografická společnost, z. s., 2017 


\section{Introduction}

Values drive human actions and shape society. Given their significance, a wide range of theories evaluate how values change, including Hofstede's theory of values, Inglehart's theory of the division of materialist and post-materialist values, Rokeach's belief system theory, and Schwarz's basic human values theory (Inglehart, Welzel 2005; Inglehart 1981). Explanantions of how the values of migrants shift frequently refer to two aspects of modernization theory, namely the acquisition of destination values by settler migrants and the diffusion of destination values to the origin through return migration. However, processes of globalization, including the intensification of flows of people, ideas, and products across borders, changes how migrants acquire and use values to pursue increasingly varied goals as economic development, identity politics, and cultural survival (Anderson 2006).

To contribute to migration theory, we extend the theorization of migrant values by focusing on the set of values linked to the influential migration-deveopment nexus. We define the migration-development nexus as the co-ordinated and enabling institutional and discursive measures that promote migrant remittances as a legitimate means of social and economic development (see De Haas 2010). Financial remittances can simply be defined as mainly money, but also payment in kind, wired/transferred or brought by migrants back home, mainly for their family members (more in World Bank 2016). Supporting migrants to remit (and in some cases to return) is regarded as a form of "globalization-from-below" and institutionalised in the so-called "migration-development nexus". The contemporary migration-development nexus draws together and coordinates the activities of many parties, including governments of sending countries and destination countries, the international community (including the World Bank, International Organisation for Migration, and the United Nations), and migrants and their networks (GCIM 2005). Yet, despite the significance of remitting for livelihoods and for economic and geopolitical transformation there remains insufficient scrutiny of changing migrant values across the migration-development nexus.

Our research therefore responds to three gaps in the current knowledge about the nature of values, and how they may be shifting. First, structural analyses of the migration-development nexus argue that states manipulate group social and cultural values of membership and belonging to influence migrant activity. This includes values referencing national identity and patriotism (Dickinson, Bailey 2007) and the values of a European superstate promoted through a cultural externalization of European borders (Van Houtum 2010). With the rise of neoliberal expectations on individualised responsibility, it is important to understand how such group values of nationalism and community are functioning. Second, the post $9 / 11$ securitization of the migration-development nexus, and the fallout of 
the global financial crisis from 2008 has meant that governments in destination countries make greater use of hard power including deportations, criminalization, and visa requirements, each of which may constrain the extent to which migrants can use values-based strategies to meet their obligations to family and communities. We do not know, for example, what impact this is having on underlying values and strategies. Third, while the migration-development nexus emphasizes financial remittances, migration theory suggests that financial remittances are strongly associated with social remittances (SR; Levitt 1998). While this research implicitly hypothesises that values existing in migrant destinations are diffused and transferred to migrant origins there have been few empirical demonstrations of this, nor attempts at integration with existing work on financial remitting. For example, is there any link between the rise of nativist anti-immigrant sentiment in destination countries and social and financial remitting? We contend that to advance migration theory we must address these gaps in knowledge about how migrant values are experienced and used under contemporary conditions of globalization and neoliberalism.

The topic of migrant values is particularly significant across post-Soviet societies, the focus of this paper. Here, the economic impact of migrant remittances is great, sometimes being the largest single source of foreign exchange. Many economies are in long-term decline with rising inequality and now rely on such remittances to meet basic requirements such as education. Yet, in conceptual terms, post-Soviet societies may not follow western-based accounts of value shifts such as those accompanying the demographic transition (Inglehart 1981). For example, while a rise in post-secular values accompanied the transition from high birth rate high death rate rural-based to low birth rate low death rate urban-based populations in the west, many post-Soviet populations have low birth rates, high death rates, and growing rural populations (Da Vanzo, Grammich 2001) which may undermine the hypothesis of increased post-secular values.

Within the general goal of investigating value experiences and use, we take a case-study approach and contribute specific knowledge about the values that Moldovan migrants who are living in Czechia hold, and selectively transfer to Moldova. We deploy Inglehart's and Welzel's definition of values, which was also included into the European Value Study in 2008 that included Czechia and Moldova, and recognises values as attitudes towards different aspects of life like religion, parent-child ties, deference to authority, levels of national pride, a nationalistic outlook, bureaucracy, economic and physical security, subjective well-being, self-expression and quality of life.

The paper is structured in four parts. The next section introduces three conceptual frameworks that shed partial light on migrant values and integrates them to formulate testable propositions. When trying to understand the whole issue in a more complex way, we evaluate Ingleharts' concept of a shift from modern to 
post-modern society and theory of modernization (e.g. Inglehart, Welzel 2005, 2008, 2010), social remittances (Levitt 1998), and Lipset and Rokkan's concept of conflicting cleavages (e.g. Lipset, Rokkan 1967). We then describe why we selected the case of Moldovan migrants in Czechia and the research methods we followed. The results are the first and original empirical findings and based on a sample of 28 Moldovan migrants living and working in Czechia, and used to assess each proposition in turn. We conclude with a discussion of the conceptual and policy implications.

\section{Literature}

Modernization theory provides the basis for assumptions about migrant values lying at the heart of the migration-development nexus. Financial remittances from destination regions back to origin areas are expected to bring gradual socioeconomic development and progressive modernisation to the origin country. As this unfolds, values are diffused from the more developed destination to the developing origin, often through migrant channels of exchange, visiting, and returning, and traditional values and beliefs about governance and gender roles, for example, are supplanted (Inglehart and Welzel 2005, 2010). Inglehart and Welzel (2005) differentiate between dimensions involving survival values and self-expression values and a second dimension concerned with traditional and secular-rational values. Survival values, or material values, place emphasis on economic and physical security. Values of self-expression, or post-material values, emphasize self-expression and self-reliance, greater tolerance for social diversity, and gender equality. They may also be associated with expectations for participation in decision-making in economic, political life and environmental protection. Traditional values emphasize the importance of religion, parent-child ties, respect to authority and traditional family values. On this dimension, social practices such as divorce, abortion, euthanasia and suicide are seen as unacceptable. Secularrational values have the opposite preferences to these traditional values. Following this framework, the migration-development nexus assumes financial remittances will trigger a shift in values from material and traditional to post-material and secular, with values such as rationality, migrant self-reliance, and democracy being prized.

However, long standing empirical evidence complicates this simplistic picture. First, the framework assumes that values are territorially-based and spatially bounded (for example, some countries are traditional, others are secular). Second, the framework assumes that values change step by step, as modernization proceeds through predictable stages. In reality, the high degree of interconnection between global communities, and transnational nature of migration with 
frequent virtual and physical exchange over borders means that values are not fixed within bounded territories, but flow through webs of social networks in comparative, relational, and even constitutive ways (Hannerz 1996). Moreover, the present reality of deepening inequality and precarity disrupts the idea that societies move from less developed to more developed, undermines the notion of a fixed temporal sequence to development and, by implication, makes it unclear why there should be any pre-determined shift of values from material to post-material, or traditional to secular values.

One branch of migration scholarship has turned to transnational and relational frameworks to provide a more nuanced account of these changes (Levitt 1998, Bailey 2001). Rather than tie values acquisition and diffusion to fixed territories or stages of development transnational accounts examine origin and destination conditions simultaneously and as interdependent. Analyses do not focus on separated origins or destinations but on migration networks and migration streams, and the ways values flow through these networks. Thus Solari (2010) studied migration from Ukraine and differentiated between streams going to California and Italy as "not simply migrations to two different destinations but fundamentally different migration patterns... the migration (of Ukrainians) to California is permanent, legal, with variation by age and gender, while the migration to Italy is temporary, largely undocumented, and mostly women over 40 . Subjectively, those leaving for California experience migration as "choice", while those leaving for Italy experience migration as "expulsion". Studying an interconnected migration system removes assumptions that migrants are assimilating to a fixed (destination) territory or returning to a fixed homeland origin, and provides a fuller reading of how values associated with working, settling, social relations, cultural reproduction, and political change work together.

Indeed, a large body of literature approaches the multidimensional nature of values that flow transnationally across destinations to origins by investigating the concept of social remittances. Defined as "the ideas, behaviors, identities and social capital that flow from receiving to sending-country communities..." (Levitt 1998, p. 927) SR are recognised as a key part of the migration-development nexus which accompany financial remittances (Levitt, Nyberg-Sorensen 2004). By learning and accepting new values, rules, ideas, behaviours, practices migrants may enrich origin society and contribute to the development of social relations including family. For Levitt (2005) values are examples of normative structures that work alongside systems of practice and flows of social capital to constitute SR. "Normative structures are ideas, values, and beliefs. They include norms for behaviour, notions about family responsibility, principles of neighbourliness and community participation, and aspirations for social mobility. They encompass ideas about gender, race, and class identity. They also include values about how organizations should work, incorporating ideas about good government and good 
churches and about how politicians and clergy behave" (Levitt 2005, pp. 2-3). Systems of practice are the actions shaped by normative structures: "these include how individuals delegate household tasks, the kinds of religious rituals they engage in, and how much they participate in political and civic groups" (Levitt, 2005, p. 3). They also include organizational practices that can help create better integrated and more effective working teams. Social capital may be defined as a set of interpersonal relationships that facilitate individuals and groups in reaching their objectives (Portes 1998).

Levitt (2005) and Levitt, Lamba-Nieves (2011) summarize the results of numerous qualitative and ethnographic accounts of SR. Unlike pre-determined value diffusion as seen by modernization theory, SR are intentional (i.e. strategic and migrant-led) and part of wider processes of cultural diffusion. They are intrinsically transnational, being transmitted through return migration, migrant visits, and exchanges of information, and "circulate, continuously and iteratively, rather than travel one-way" (Levitt, Lamba-Nieves 2011, p. 19). As Isaakyan and Triandafyllidou (2016) argue, destination conditions matter. This also means SR are conditioned by people's experiences prior to migration (i.e. in the origin) including gender, class and life-course factors, and by relative differences between sending and receiving countries. For example, Vianello (2013) examines the circulation of gender roles and documents how Ukrainian women in Italy transfer concepts of the right of self-care and self-realisation and generally more women-friendly life-course patterns to social networks in Ukraine. Moreover, SR "often reinforce and are reinforced by other forms of global cultural circulation" and may be seen as constitutive of, rather than subject to globalization (Levitt, Lamba-Nieves 2011, p. 3).

However, there is a general lack of empirical data on how values circulate as part of SR across post-Soviet societies (Grabowska, Engbersen 2016; Krzyžowski 2016, are exceptions). While Levitt's original concept is based on her research on the Dominican Republic and the USA during the 1990s, we may expect the securitized post $9 / 11$ and post global recession context of former Soviet republics to be distinctive. Indeed, the breadth of the concept of SR may undermine its applicability (Nowicka, Šerbedžija 2016; Boccagni, Decimo 2013; Lacroix, Levitt, Vari-Lavoisier 2016), including to the specific circumstances facing post-Soviet societies (Grabowska, Garapich 2016, Sandu 2010, 2016).

To further develop our account of migrant value experiences and use in the post-Soviet case we supplement modernization theory and the SR concept with the concept of cleavages as introduced in political science by Lipset and Rokkan (1967) and Römele (1999). This links the acquisition and circulation of values to the multiplicity of opposing and conflicting interests rooted in the social structure of society (Römele 1999). Based on analyses of so-called national and industrial revolutions which took place in the west between the $16^{\text {th }}$ to the $19^{\text {th }}$ 
centuries, various cleavages between, for example, centre/periphery, state/ church, city/country, and owners/working classes have been posited (after Lipset, Rokkan 1967; Rokkan 1999a, 1999b). While the concept appears context bound, Rokkan argued for a research design that is case-study driven, and allows for analysis of the unique historic and geographic circumstances of potential cleavages (Crewe 1994). Drawing attention to context-specific structural factors can provide a counterweight to accounts of autonomous behaviours implied in SR (Luptáková 2009). Moreover, in concert with structural accounts of migrationdevelopment nexus, Rokkan considered the most important cleavage to be that between owners and workers. He argued its impact was homogenizing and stabilizing, that is suggesting, potentially in contrast to SR concept, continuing inequality for workers (Hloušek 2002).

In summary, this brief review of literature on how migrants experience and use values suggests that current frames may each shed a partial light on changes under conditions of globalization but, when considering the post-Soviet case, an integration of the frames of modernization theory, social remitting and cleavages will lead to an understanding of the whole issue in a more complex way. Accordingly, we take a step to bring these frameworks together by proposing three testable propositions. First, migrants acquire and experience values in transnational ways by comparing situations in their daily life in the destination with their former (and in some cases imagined future) life in their origin. The simple question is, are values acquired locally, or transnationally and relationally? Second, we evaluate the tenet of SR and the migration-development nexus that values experienced in a destination are transferred back to, and used in the origin. In contrast to modernization theory, which sees the predictable diffusion of postmaterialistic characteristics and "copying" from destination to origin, we examine context specificity by studying the particular historic and geographic patterns of cleavages in the origin society, and linking these to structural conflicts which impact the circulation of values between destination and origin. Third, the use of values through migration networks both responds to, and reinforces underlying cleavages, and becomes part of a constitutive explanation of continuing structural inequalities between origins and destinations. To examine these propositions we undertook a case study approach and study in depth one migration system we introduce below.

\section{Case-study of Moldovan migrants in Czechia}

Our empirical focus is on migrants from Moldova who live in Czechia and maintain ongoing connections with Moldova. Here we describe why this migration system is a compelling case study of value changes across post-Soviet societies. 


\subsection{Factors influencing migration from Moldova}

Like other post-Soviet societies Moldova has experienced sustained population decline and tough economic conditions. Estimates of the size of the population have fallen from a high of 4.3 million in 1989 to perhaps some 2.6 million (including "Pridnestrovian Moldovan Republic") at present (see e.g. Moldavsko 2017). Moldova ranks among the poorest countries of Europe (Dugoglo, Onofrej 2016). Moldova does not have any notable mineral sources at its disposal and almost $80 \%$ of its energy is imported from Transnistria, Romania or Ukraine, draining the country economically. $62 \%$ of the population live in rural areas and $30 \%$ of economically active inhabitants are employed in agriculture (Transnistria is an exception being $70 \%$ urbanized, Noviková 2015). However, opportunities for young adults are constrained by many factors, including earnings in rural areas being only two thirds of those in cities, higher costs of living, low access to drinkable water, and the difficulties of providing care to the elderly people who move there to live out their lives. While the country has been, since 1991, a united "state", with one constitutionally recognised autonomous territory (Gagauzia) it has long been ethnically diverse. Ethnic groups living in Moldova include Moldovans (75\%), Romanians (7\%), Ukrainians (6\%), Russians (4\%), Bulgarians (1\%), and others (Demickij 2016).

It is estimated that 700,000 Moldovans work abroad, which is roughly every second member of the country's work force. People aged between 18 and 44 are the most likely to emigrate, although all strata of the population are drawn to the process of migration (Extended Migration 2012). Expectations that the worldwide financial crisis in 2008-2009 would lead Moldovans to return home in large numbers did not eventuate. Indeed on the contrary, the worldwide financial crisis stimulated further migration which is still continuing at a high rate today, even after the end of the financial crisis. Moldovans take advantage of the recent removal of short-term visa requirements for EU countries (to 28.4.2014) and travel to work there, although many of them work illegally, which is persistent feature of Moldovan migration (Mošnjaga 2012).

This emigration is generally held to be responsible for the modest aggregate improvements in Moldovan economic conditions between 2006 and 2016. The average monthly income increased from 100 to EUR 240 while the minimum wage went from 60 to EUR 95 (Mošnjaga, Lupták 2008). But, with about 800,000 of Moldova's inhabitants living below the poverty line (Dugoglo, Onofrej 2016) mass migration abroad has become a survival strategy for the population. Push factors include a mix of poverty, unemployment and low incomes, deindustrialization, the lack of job opportunities for qualified people, and the erosion of the social infrastructure in health services, education and housing. One motivation for this recent wave of migration is the diversification of potential risks of a future 
economic crisis (Mošnjaga 2012). Migratory pull-factors include high earnings abroad, opportunities for personal development of migrants, migratory social networks, ultimately predetermining the direction of migrations - from eastern parts of the country and from villages towards Russia and from western areas and cities to, for instance, Italy, Germany or also Czechia (Mošnjaga, Lupták 2008).

As a sending country Moldova gives us opportunities to assess our propositions. In the post-Soviet era, Moldovan society has been affected by regressive processes of "social involution" (see Lupták, Luptáková 2013; Inglehart, Welzel 2005) that can be interpreted using the cleavage concept (Lipset, Rokkan 1967). We argue that Moldovan society is subject to opposing and conflicting interests stemming from three main cleavages: (a) centre/periphery (Chişinău and the south of the country), (b) city/countryside (growth of population in the declining countryside), and (c) owners/workers (low incomes of working people, weakly developed social infrastructure). However, we do not regard a cleavage between the state/church as conflictual in Orthodox Moldova, something we postulate is linked to the Byzantine tradition of harmony between church and state. Thus, with respect to religion, $93 \%$ of the population claim to profess membership of the Orthodox Church and even though Moldova does not have a state religion the Orthodox Church plays a key role in the structure and legitimacy of the state (Charitonová 2015).

\subsection{Czechia as a migrant destination}

Moldovan-Czech migration is representative of an important, long-term outflow of people from one of the poorest European countries to a much richer Czechia. The latter country, though having the same post-communist heritage like Moldova, was due to many factors, unlike Moldova, able to go through deep socioeconomic and political transition and transformation processes relatively successfully while also maintaining and then increasing living standard of its population. This was a precondition for becoming an important regional migratory magnet, attracting international migrants including Moldovans (Drbohlav 2011).

We are particularly interested in Czechia as a destination because it shows post-material value orientations and a contrast with Moldova. Comparison of these two dimensions in Czechia and Moldova shows a big potential for change of values and beliefs particularly the survival and self expression dimension (see Figure 2.1., in Inglehart, Welzel 2005, p. 57). To illustrate this, the typology in Table 1 is based on Inglehart's (1981) original four-item battery of questions, where items indicating materialistic orientation are "to maintain order in the country" and to "fight against rising prices" and post-materialist indicators are "to give people more opportunity to speak in important government decisions" and "to defend 
Tab. 1 - Materialism and post-materialism values (in percentages, 2008) by selected countries (survey results)

\begin{tabular}{lccc}
\hline & Materialist (survival values) & Mixed & $\begin{array}{c}\text { Postmaterialist } \\
\text { (self-expression values) }\end{array}$ \\
\hline Czechia & 27.9 & 62.6 & 9.5 \\
Moldova & 49.9 & 45.6 & 4.5 \\
EU15 & 22.3 & 62.7 & 15.1 \\
\hline
\end{tabular}

Source: own calculation (based on EVS 2008)

freedom of expression". The respondents, who selected materialistic answers as their first and second choices are described as "materialist", those whose first and second choices were post-materialist items are considered "post-materialist". Any combination of materialism and post-materialism answers gives rise to the "mixed" type. As Table 1 suggests, Czechia exhibits levels of post-materialism two times higher than in Moldova (see more generally to this topic in Inglehart, Welzel 2005, 2008, 2010).

\subsection{Research method and analysis}

In order to achieve our goals we conducted 28 semi-structured in-depth interviews with Moldovan migrants. To represent the diversity of migration to Czechia we used the following criteria to select respondents: (1) To have his/her family members(s) in Moldova or other very close person(s) with whom he/she is in a close touch; (2) he/she remits money (no matter how much and how often); (3) he/she perceives that his/her relations to Moldova are strong; (4) he/she must be able and willing to share his/her experience with researchers (to talk to us); and (5) he/she has to be in Czechia for 6 month as a minimum at the time of the survey (adding up more short-term stays realized within a short period was accepted too). The interviews were carried out by members of our research team GEOMIGRACE in a capital city of Prague (24) and the city of Pardubice (4) between February and April 2017. The interviews were conducted in Czech (17), Russian (10) and English (1). To reach our informants we used contacts within already settled post-Soviet communities and contacted local churches. The interviews were made in premises of the Faculty of Science, in the city centre of the capital.

To assess the three propositions above we collected information on our respondents' personal backgrounds, migration patterns and strategies, integration experiences in Czechia (including in the realm of work and education), relations with Czech society and other migrants, and value orientations. To test and finalise 
Tab. 2 - Interview prompts on social remittances

Prompt

Moldovans are exposed in Czechia to new ideas, new behavioural models and new societal rules. Please give examples e.g. from religious, political, social, health, educational, economic/business areas (e.g. work practices), lifestyle, family relations. Do you accept some of these new patterns since you feel it enriches you?

Which of the following new patterns (ideas, behavioural models, societal rules) do you endorse and would you endeavour to transfer to Moldova: (a) wage level and social system level, (b) respect to human and civil rights and freedoms, (c) security, order, low criminality and tidiness in streets and public spaces, (d) the way as employers treat their employees, (e) quality of housing, (f) quality of public transport, (g) educational system, (h) interpersonal relations, (i) system of children and family care, (j) the way how administration works.

Have you already lost (abandoned) some elements of the social and cultural habits with which you arrived at Czechia? Do you keep ties to your mother country - with whom and how do you communicate with them? If you have children who stayed in Moldova, please, describe who cares about them? Do you support them and how? Do you teach them some new habits, practices you learned in Czechia? How often do you travel to visit your family in Moldova? What do you do in this time?

Are you going to apply some of these new patterns after returning home to Moldova? - which of them? Or, in fact, have you already been doing this when visiting your family or communicating with them? In your view, will your family members spread further these innovations? Please, elaborate on this.

What are your plans for the future? To stay in Czechia for a long time or forever? To return back to Moldova? To migrate further to another country? Why did you design such strategy - has it been changed over time? What was the reason of that change?

Source: own research

the most effective prompts that elucidated these values we conducted a pilot study with four informants in December 2016 and January 2017 (see Table 2 for the form of prompts we used in the final interview).

Our analysis was made in three steps. In the first step we searched for how respondents reflected on any newly perceived ideas, behavioural models and societal rules, noting if they described these by comparing Czechia and Moldova. In the second step we examined any new values, behaviour, societal rules which had already been endorsed and accepted by the informants (or by somebody they knew) and actively incorporated in their lives (or lives of somebody they heard about). The third step identified modes of value transmission used between Czechia and Moldova, including respondents' migratory strategies, type, frequency and quality of contacts with relatives and acquaintances in Moldova. As our topics within the interview were clearly defined and oriented to our propositions, we completed these tasks without using proprietary software sometimes deployed to build grounded theory. Nonetheless, we recognise some limitations in our approach. We are introducing a qualitative study which aims to increase understanding of our three propositons but which would need further analysis to extend the generalizability of what we report below. Second, the qualitative study is based on self-reporting. Hence, informants' answers may partly be influenced by memory and/or social desirability factors. Third, despite trying to 
get heterogeneous informants, we might miss some representatives of important migratory types. Also, duration of residence affects value acquisition and we note that some of our respondents arrived in Czechia recently.

\subsection{Moldovan migrant sample}

Below we introduce the general characteristics of our sample. Table 3 confirms that our respondents were widely drawn across categories of sex, age, marital status, educational level, and profession. As has been demonstrated in other studies,

Table 3 - Characteristics of Moldovan informants

\begin{tabular}{|c|c|c|c|c|c|c|}
\hline & Respondent's name & Age & Sex & Education & Family status & Profession in Czechia \\
\hline 1 & Jordan & 33 & man & secondary & married & sales representative \\
\hline 2 & Irena & 40 & woman & secondary & married & cook \\
\hline 3 & Marina & 27 & woman & university & single & manager of logistics \\
\hline 4 & Valerij & 25 & man & secondary & single & worker in construction \\
\hline 5 & Dorina & 26 & woman & university & married & worker in construction \\
\hline 6 & Igor & 28 & man & basic & married & worker in construction \\
\hline 7 & Míša & 29 & man & basic & married & armature \\
\hline 8 & Julian & 22 & man & secondary & married & worker in construction \\
\hline 9 & Alexandra & 20 & woman & studying & single & student \\
\hline 10 & Uance & 50 & woman & secondary & married & cleaning woman \\
\hline 11 & Radu & 26 & $\operatorname{man}$ & university & registered partnership & marketing specialist \\
\hline 12 & Irina & 28 & woman & university & widow & cook \\
\hline 13 & Lilia & 47 & woman & secondary & divorced & $\begin{array}{l}\text { auxiliary work force } \\
\text { in the kitchen }\end{array}$ \\
\hline 14 & Líza & 23 & woman & secondary & married & chambermaid \\
\hline 15 & Grigori & 27 & woman & studying & single & student \\
\hline 16 & Máša & 57 & woman & university & divorced & dressmaker \\
\hline 17 & Marcel & 30 & man & basic & married & $\begin{array}{l}\text { worker in construction - } \\
\text { parqueter }\end{array}$ \\
\hline 18 & Angela & 30 & woman & basic & married & chambermaid \\
\hline 19 & Efim & 30 & $\operatorname{man}$ & university & married & worker in construction \\
\hline 20 & Maxim & 31 & man & university & single & plaster boarder \\
\hline 21 & Alena & 48 & woman & secondary & married & salesperson \\
\hline 22 & Vasilisa & 56 & woman & secondary & married & $\begin{array}{l}\text { auxiliary work force } \\
\text { in the kitchen }\end{array}$ \\
\hline 23 & Selina & 51 & woman & secondary & married & $\begin{array}{l}\text { worker in the food } \\
\text { industry }\end{array}$ \\
\hline 24 & Tumor & 61 & man & secondary & married & self-employed \\
\hline 25 & Iryna & 39 & woman & university & married & cook, cleaning woman \\
\hline 26 & Oxana & 46 & woman & secondary & married & cleaning woman \\
\hline 27 & Tamara & 51 & woman & basic & married & chambermaid \\
\hline 28 & Timur & 45 & $\operatorname{man}$ & basic & divorced & worker in construction \\
\hline
\end{tabular}

Source: own sample 
our respondents also had high rates of double citizenship, with half holding both Moldovan and Romanian citizenship. On average, the length of informants' stay in Czechia was 7.7 years (minimum - 0.6 months, maximum - 21 years).

The majority of migrants are women, in keeping with the continuing gendering of Moldovan migration observed elsewhere. Over one third have university education but few have found employment commensurate with such skills and training. Notably, only five of the 28 migrants are currently single, although the high rates of being/ever being married do reflect the relatively older demographic profile of this group.

\section{Results}

In the following section we select illustrative quotes to highlight the most frequently mentioned values and how migrants acquired and experienced these values. The discussion is organised according to each of our propositions.

\subsection{Values and daily life}

This section identifies the values that Moldovan migrants have experienced in Czechia. Respondents were asked to give examples from religious, political, social, health, educational, economic/business areas of any new values and patterns they acquired and have experienced since moving to Czechia (see Table 2). We found two broad "topical" responses as below.

\subsubsection{Law and order}

Informants appreciated the sets of rules and the overall system of "law and order" that functions widely across many public and private layers of Czech society. They noted that rules existed "de jure", in the sense of written procedures, and also "de facto", in the sense that the conduct of Czech daily life involved "respect" for the system of law and order. The Czech police were often mentioned as an exemplar:

"People have respect for police here in Czechia (and I like it here), the exact opposite of Moldova." (Efim)

"As for the police, here a natural respect is larger, it is rather enforced there (in Moldova)... fear dominates over respect." (Irina)

"I like that people know here what they rights/entitlements are and they behave accordingly -it concerns work, housing, administration ... Moldovans in Moldova do not know such rights, especially vis-a-vis authorities..." (Marina) 
Respondents also extolled the value of order and reliability when they compared their daily transport activities and waste disposal activities with their prior experiences in Moldova:

"Here the transport works according to timetables." (Angela)

"Roads are good here and bad there." (Igor)

"I am literally spoiled by public transport system in Prague. When I travelled home, I wanted to quickly return also because of the Prague transport system." (Maxim)

"Tidiness is here, we do not know it in Moldova." (Efim)

"In Moldova there is far less inorganic waste than here but garbage is more visible, possibly in fields or variously a lot of illegal waste dumps and nobody simply deals with it." (Gregori)

The informants generally appreciate how work, health and education systems are transparent in Czechia.

"You can get job here and you know how much money you will make. If you have a job in Moldova, you will make very little (about 100 EUR a month)." (Uance)

"Your educational system is excellent, my both children study here and we pay nothing, only school aids and lunches. You pay for everything in Moldova - e.g. for heating, facilities in classrooms etc." (Irena)

"If you go to see your doctor, you can arrange this appointment and then you do not wait ... Or, if there is an accident - somebody fell off his/her bike on a street, ambulance will not come there in 30 but in 15 minutes. They are still waiting for the ambulance in Moldova and an injured person can be dead ..." (Alexandra)

"The health system is better here. In Moldova - you go to a hospital and if you do not have money they ignore you." (Angela)

These positive aspects of Czech society were almost always described in relative and comparative terms that is by invoking less positive experiences of daily life in Moldova before migration. The most important aspect of daily life to be cited was rampant corruption:

"I like it here (...in Czechia...) more than in Moldova. The problem is that in Moldova all is related to corruption and also very small amounts of money are paid to welfare system, therefore it is a bad model." (Maxim)

"Police is horrible in Moldova - all the time they take money, they get and they take it." (Igor)

"There is no chance to solve anything in Moldova, everything depends on bribing." (Irina)

"Children in a kindergarten learn new things all the time, they go outside ... In Moldova you have to provide an educator with gifts, chocolate ... every morning you pay." (Marcel)

"A student will not study at a university in Moldova - he/she will bring money there. $\mathrm{He} / \mathrm{she}$ got it from a mum who sent it from England. Studying is not for getting a new knowledge but for getting a degree" (Marcel).

"You can also buy better marks." (Grigori) 


\subsubsection{Social values}

Migrants also experienced social and cultural values in Czechia in relation to those norms they had previously experienced or held in Moldova. Alexandra implied Czech society was more open when she explained how people in Moldovan society scrutinized what she was wearing:

"In Moldova they watch you carefully what did you put on. Here in Czechia, it does not matter, you can put on any clothes, you can get into dirty jeans. People in Moldova will cast a slur on you because of this..." (Alexandra)

There was also a sense in which life was seen to be more balanced in Czechia, with greater opportunities for autonomy and control. Some informants used the example of health, and said they valued the possibilities for a healthful life in Czechia, comparing this against their experience of traditional and pre-planned life before moving:

"You live a normal life here in Czechia. Nobody thinks of good for his/her health in Moldova-you go somewhere to work hard and all the money you made must be invested into a new house, or in reconstructing an old one, regardless of anything else." (Marcel)

"People drink less spirits here than it is at home (in Moldova)." (Maxim)

Migrants also commented on the more supportive workplaces and values in Czechia, again linking these back to previous experiences in Moldova. In Czechia the greater personal freedoms and more humane attitudes toward workers were seen as positive:

"It is also more civilized... there is better behaviour towards people. In the kitchen (employment) all people are nice and they explain everything to me." (Iryna)

"I remember working in Russia, when you wanted only two or three minutes to take a breather they started to shout at you right away: 'Come along! Snap up...' Thus generally those values, when comparing to Europe from the point of view of that human approach or whatever, and Europe has much more to give, I would say." (Efim)

"Here in Czechia when we have some hard work our boss would come and calmly say: 'Guys, take a break, at least ten or fifteen minutes, and then you can continue...' It would have never happened in Russia, for sure." (Efim)

However, migrants generally felt that gender roles and values were similar in Moldova and Czechia:

"Generally speaking it (the role of women) is possibly the same, I do not feel any difference." (Iryna)

"I don't see difference because we have businesswomen in Moldova, too, and a woman could be a director of a company like here, I think there are hardly any differences and I believe that it is like that everywhere except for some really underdeveloped countries. It happens in Moldova sometimes that a woman is a head of a family, she could also have a higher income; it is the same as here. It depends, but I would say that there are basically no differences between Czechia and Moldova." (Marina) 
"A woman in Moldova is wife and husband at the same time, she must do everything and also do men's work; she may chop wood. The reason could also be that men often go to work abroad and then the whole household depends on the woman and she has to do the man's work too." (Oxana)

However, while comparisons of law and order revealed positive inclinations toward the "new" values experienced in Czech daily life, and while some also spoke favourably of more open attitudes in Czechia, when Moldovan informants spoke of values about family relations and practices in Czechia they were less positive. Rather, they emphasized the importance of traditional family values they had previously experienced in Moldova, juxtaposing these to the more liberal and "secular-rational" values they saw in daily life in Czechia:

"I would say that respect in a family is very important and that overall the emphasis on the family is greater (in Moldova) than in Czechia." (Marina)

"Relations between children and parents are too much open (in Czechia)." (Alexandra)

Such "new" family and partnership patterns, or other aspects related to social acceptance of phenomena such as divorce, euthanasia, abortion, or homosexuality were generally rejected, or even condemned:

"It is wrong when people divorce." (Efim)

"As for abortions or euthanasia, there (in Moldova) it is, I believe, a greater taboo surely, they don't speak about it there..." (Gregori)

"So you don't have so many cases (of homosexual couples) there as here (Czechia), it is a bit of a taboo there and you don't like to talk about anything... it almost does not exist there or just minimally." (Gregori)

"I would say that the foundations of the state should be the family... so it seems to me that it (homosexual couples) is wrong. It's not that I should not see them or whatever, but it is their problem and generally it is a degradation of the whole society." (Dorina)

These different value systems were often made sense of with respect to the powerful role of religion in Moldovan daily life:

"Religion has much less influence on life here on the whole... I mean, traditions are maintained here, too, but generally speaking people do not go so often to churches... you don't see here for instance crosses every all over a house or in cars, it's a difference from Moldova. There is a more atheistic approach here, and it projects pretty well into the life and in solutions of some problems, either family or other ones." (Gregori)

Overall, we report that migrants experience values through a process of relating them to their prior experiences from daily life in Moldova. Values of postmaterialism such as desire for autonomy and freedom of choice were significantly more likely to appear in discussions of the positive aspects of Czech organizational rules and the conduct of everyday life, and less likely to appear when respondents spoke of family relations. We did not encounter evidence of migrants "absorbing" Czech values per se, but rather assessing values in the specific contexts of their daily lives and previous experiences in Moldova. In this sense, value acquisition 
is a transnational process, simultaneously referencing origin and destination, with migrants experiencing values as part of their daily lives in transnational networks (cf. Solari 2010).

\subsection{Diffusion of values from Czechia to Moldova}

This section evaluates the tenet of SR and the migration-development nexus that values experienced in Czechia are transferred back to, and used in Moldova. In contrast to modernization theory, which sees the predictable diffusion of postmaterialistic values and "copying" from destination to origin, we examined context specificity by studying the particular historic and geographic patterns of cleavages in Moldova, and linking these to structural conflicts which impact the circulation of values between Czechia and Moldova.

\subsubsection{Information exchange}

Modernization and SR frameworks argue that values flow through specific channels. We did find evidence of migrants' exchanges of information, migrants' visits, and migrants' return short-term migration, but no evidence of relative visits. As part of their transnational lives, informants kept in touch with their family members and friends in Moldova often on a daily basis via phone, email, skype, facebook and other social media. They chat while informing each other about their lives, problems, challenges and achievements. Furthermore, as indicated above, most of our informants travel back to Moldova. Some visit for one or two weeks there, sometimes longer, and stay with family members and friends, sharing experiences of their stay in Czechia. However, despite such interactions, migrants indicated they are not likely to be significant for value diffusion as the ongoing transnational connections across the migration system meant that most information on Czech daily life and its values were already very well known before any visits took place:

"... when we started to go for the first time people naturally used to ask a lot, yeah, what about and whatever, how is the life there. Thus something like the export of the information and comparisons was major but recently they already know almost everything. It is also influenced by the fact that we communicate via Skype and we talk to each other a lot in the course of a year and we talk about things in this way, so on our visits home we are primarily glad to see each other." (Gregori)

This is an important finding because it reinforces the view we describe above that values are not suddenly acquired, but emerge in relational ways, as migrants experience new situations in Czechia and make sense of these by referring back to their previous experiences and socialization in Moldova. It means values circulate across the origins and destinations according to the daily experiences of migrants 
in these two places. As such, it may be more productive to speak of value circulation rather than diffusion, or transfer per se.

\subsubsection{Negotiating cleavages and conflicts in Moldovan society}

Our informants were noticeably guarded about the potential for transferring their experiences of Czech values to Moldova specifically and social remittances more generally. Igor was blunt:

"I know that migrants moving between Czechia and Moldova did nothing in relation to things you are asking about." (Igor)

"When migrants return to Moldova, they rather adjust. Their impact upon changes in society is minimal." (Julian)

In fact, of 28 respondents, just three spoke directly of potential positive impacts of the knowledge and values they experienced in Czechia for Moldova and, when they did, they also expressed worries and constraints. Their accounts also confirmed the view that SR are most likely in the presence of financial remittances. They stressed the possibility of circulating normative structures (for example, how organizations should work, and good government) and systems of practice (for example, organizational practices) (Levitt 2005). They used examples of bringing from Czechia to Moldova new private businesses, services, or public projects. Marcel explained that:

"Regarding the construction works, to work with stucco is not known in Moldova. I learned it in Czechia. Or, the Internet business when you order something via a phone and they will deliver it to your house, it is something I like and I would like to apply it in Moldova..." (Marcel)

Many saw the "Moldovan business environment" as a major constraint:

"I would like to start a business with tyres. I know a guy who learned in Czechia everything regarding this business area. He was not successful, however, in prolonging his visa in Czechia, so he returned to Moldova and he started a company of his own. He bought mobile cranes and other construction equipment/facilities which he also, from time to time, rents too. This story is, however, sporadic. Many people are worried about conducting their own business..." (Jordan)

"As far as the construction is concerned, I have no education. Nevertheless, I learned something and I can make use of this experience at home, when working on my house. To start a new business based on my current knowledge, however, I am not able to cope with it." (Efim)

"All Moldovans who work here (in Czechia) invest their money at home - but they put money into their families (house, education, children) ... to start a business is risky due to unstable situation." (Máša)

Respondents in turn linked this poor business environment to corruption and the low purchasing power of Moldovan population: 
"Earlier I was interested in sports, all services and tools were free of charge. Now, all, absolutely all, you have to buy. Desire to do sports is enormous but there is an obstacle that it is expensive hobby. Moreover, to start a business means to meet omnipresent corruption." (Maxim)

"What works here (in Czechia) not always works in Moldova. As far as doing business is concerned, it is complicated in Moldova, or even very complicated... It is not because people would not want to buy products... but there is a bad business environment. I intended to sell ironware they do here in Czechia. So far, however, there has not been demand for such sophisticated products which the Czech market offers. All revolves around prices. Such products would simply be unsaleable." (Maxim)

We believe that these patterns also reflect deeper cleavages that have intensified in Moldovan society since 1991 . The low purchasing power and poverty is linked to the significance of the centre/periphery and city/countryside cleavages. An example of centre/periphery cleavage is the Pridnestrovian Moldovan Republic which broke away from Moldova in 1991 and declared its independence as a manifestation of the categorical disagreement of the Russian speaking population of Transnistria with the politics of pro-Romanian oriented Moldova. Independence from Moldova has not, however, so far been recognised by the international community (Charitonová 2015). The separatist Pridnestrovian Moldovan Republic which is de jure a part of Moldova but is not so de facto due to its separatism. The majority of Moldovan industry, built in the Soviet era, was in the territory of the separatist Pridnestrovian Moldovan Republic. Moreover, Transnistria also went through conflict and takes up about one eighth of Moldovan territory with more than half a million people live there (Mukomel, Pajn, Popov 1999). Moreover, the city/countryside cleavage continues to deepen, with the number of people living in the countryside gradually growing (Dugoglo, Onofrej 2016).

These cleavages affect other aspects of conflict. Ongoing centre/periphery cleavages have worsened economic conditions, delayed the development of market conditions, prompted emigration, and most widely undermined the government. Indeed, we acknowledge Rokkan (1999a, 1999b) who argues for a government/ society cleavage, and here we link the numerous comments we received about corruption and the lack of law and order in Moldova to a government/society cleavage.

We also argue that the paucity of SR per se can be interpreted by the way that the state/church relationship works in the Moldovan context. By not being a source of conflict, but rather a source of stability, the more traditional material values associated with long standing Orthodox beliefs persist, and make family values a source of stability and security for migrants in Czechia. This minimizes the perceived need for more secular values. The strong role of religion and emphasis on a large and strong family implies the continuation of transnational patterns of circulation rather than simple diffusion of post-material values to Moldova. Thus 
the church becomes a legitimate institution that becomes involved in the use/ circulation of values by playing a coordinating and gatekeeping role:

"For example, there is one village where they opened a bank account and everybody who migrated can contribute 10-15 EUR. This money then goes to school, kindergarten... it is for the village. Or, they come from abroad and donate to charity in a church. Then, who needs can get the money... In church, they know who needs help." (Marina)

In summary, we find little evidence to suggest that post-materialist values in Czechia are diffused and transferred back to Moldova. Rather than copying from destination to origin, we see a limited and selective transfer of values between origin and destination. The paucity of direct transfer is consistent with the ways in which the presence of cleavages have caused structural barriers in Moldovan society, especially around corruption and market demand, and the absence of other cleavages, notably church-state, have given traditional models of family legitimacy and enabled the church to work as a gatekeeper somehow in parallel with the (corrupt) state. This context-specific transfer is working in ways specific to the Moldovan-Czech migration system and the particular historic and geographic way in which cleavages are being negotiated by migrants. This helps explain why the continuing poor economic conditions and strong role of the church give rise to generally materialistic orientations and why our informants often perceive post-material values in many areas but they are slow accept them and so to pass them on because the material values of modern, industrial society linger on rather than the post-material values of a post-modern society. Any newly acquired experience is not able to outweigh the heritage of both past and present.

\subsection{Constitutive relations}

In this section we comment on how the use and circulation of values, which responds to structural barriers of corruption and market demand as above, may further reinforce underlying and ongoing cleavages in Moldovan society. Here we pick up on the suggestion made by Rokkan (summarised in Hloušek 2002) that the cleavage between owners and workers is particularly significant, and has a homogenizing and stabilizing impact with continuing structural inequality.

We base this discussion on questions we asked about applying values after returning home to Moldova, the likelihood of family members spreading innovations, and future plans and strategies for mobility (see Table 2). Julian, one respondent who was considering returning to Moldova, summarized the issues that many migrants were facing:

"I want to bring my wife here (Czechia) in order for her to see it. I am adjusting to the local behaviour. Everything works according to rules, people respect each other. Drivers 
stop at a crossing, nobody yells in a shop, nobody jumps the queue. The situation will perhaps be better in Moldova over time too." (Julian)

His is a material-value and family based strategy (reunification with his wife) which leaves open the possibility of a return to Moldova if economic conditions improve there. His point that the respect of rules was "an adjustment" for him, implying that Czech life is more rule-based than Moldovan life, echoes another quote from Gregori that implicitly criticizes Czech women for using such a "rule based" strategy to fight for gender recognition as an individual rights. This he saw as opposed to (Moldovan) traditional family-based (kin) values:

"I would say that something like that European pattern is valid here, that it seemed to me that there were a lot of feminists here, much more than there. Thus - how to put it - they rather fight for their rights but as a result it seems they rather fight against that traditional model, yeah, that they simply want like more rights but in fact they are disappointed that their plans or their family life did not turn out well... Strictly speaking, it does not exist at all in Moldova..." (Gregori)

What this suggests is that any transfer of post-material gender roles and norms will depend on how the tension between secular and rights-based attitudes in Czechia and traditional family beliefs in Moldova is resolved by migrants and their families. As such family beliefs are bolstered by the Orthodox church, and the church has a non-conflictual relationship with the state, and is seen as a source of stability and security, it seems likely that gender norms will be slow to change (cf Vanore, Siegel 2015).

We saw similar patterns with respect to the potential for changing class positions and reducing income inequality. In Moldova, cleavages had created poor economic conditions and forced migrants to work overseas and remit, often to support families and communities: For example:

"We help via sending money for reconstruction of our school. For example, we opened a new museum in the school. I am not saying that I sent millions - what I could, I contributed... I attended that school and I am glad that the museum is here now." (Irina)

"Yes, migrants assist in building a playground and kindergarten for children who have no parents..." (Angela)

"There are some migrants who work abroad. They do some things at home - they build houses, buy a car but also may contribute to reconstructing streets or building a new playground - they do it together, two or three, this is my experience of my region, but I do not know how is it in other regions? A playground in my town was made in an empty courtyard through this model..." (Efim)

The combination of financial and social remitting strategies seem to keep open a diverse range of opportunities for geographic connection with Moldova, including immediate, delayed, eventual, and even non-return to Moldova. Half the migrants did not have immediate orientations to return to Moldova and many of these ruled it out in the future. They mentioned economic (career) and/or family reasons. Four 
informants declared their current decision as staying in Czechia, but said they had not excluded returning in the near future. Another seven informants hesitated as to how to answer the question and admitted that they may return after studies have been finished (Marina) or if the economic situation in Moldova is better (Julian). Of course, remaining to study and work in Czechia may be associated with the further orientation to and use of material values.

We thus see a potential contradiction between the dominant migration-development nexus assumption that migrants hold values of remitting as a democratic grass-roots form of globalization from below with the potential to empower the unempowered and, at least concerning the Czech-Moldovan migration system, the selective transfer of values in ways that seem set to deepen ongoing cleavages in Moldova. That is, financial remittances are somehow bound up in the bare minimum provision of social services to Moldovans (owner-worker cleavage) while also giving opportunities for those with influence to succeed from non-formal strategies including bribery (government/society cleavage). We heard that many respondents blamed the Moldovan government for the lack of jobs, or well paid jobs, and attributed this to state's failure to get to grips with corruption and bribing:

"The money put into infrastructure is usually lost and will not find given recipients. Somebody takes all money (charges for transmission of remittances and other services, payments for electricity, water etc.). It is immediately lost from the accounts. This is typical Moldovan Policy! Money which is sent by European Union via aid is lost, or properly speaking, money is stolen. Governmental officials are behind this they have had highlydeveloped schemes through which they steel aid from European funds." (Maxim)

"When having corruption or misappropriation of the public finances in Moldova, they do not try to hide it too much ... it is much common there. I would say that the "mental inner order" is different there." (Gregori)

"Every year the Moldovan government sets more and more expensive 'contracts' for studying at a university. The prices are so high that many people cannot afford to pay them and migrate abroad." (Irina)

\section{Summary and Conclusions}

We have argued that understanding how migrant values change is of significance not just to the operation of the migration-development nexus but, more broadly, sheds light on how societies are shaped and inequalities persist. To contribute to theoretical advancement we have presented the first study of how Moldovan migrants in Czechia acquire, experience, and selectively transfer values. Our main results are first, migrants acquire and experience values in transnational ways that go beyond their immediate circumstances. That is, they acquire and 
experience values in relational ways by comparing daily life in Czechia with their previous practices and experiences in Moldova. A majority of migrants consider the new reality to which they are exposed in Czechia mostly in terms of "the modern exposed to the more post-modern" (see more in Table 1, Rabušic 2000). Most importantly, the situation in their country of origin is as important as the conditions they encounter at their destination(s): values are inherently place-based and relational. Values were related and compared with reference to the mundane and ordinary activities and experiences respondents had in daily life - including wearing clothes, using public transport, accessing information, and family norms.

Second, we did not find evidence of linear diffusion or copying of values from Czechia to Moldova. SR did accompany financial remittances but to a very limited extent. We found that SR are enabled and constrained by cleavages and structural conflicts in Moldova. For example, normative structures (namely, how organizations should work, good government) and systems of practice (organizational practices) were the most likely values to be selected and transferred. However, and going against the assumption of the migration-development nexus and institutions promoting return migration as a development strategy we found that, at the present time, very few repondents were actively planning an immediate return to Moldova. We are not able to subscribe to Inglehart's and Welzel's (2005, 2008, 2010) position that "socioeconomic development tends to transform people's basic values and beliefs ... in a roughly predictable fashion"; "economic prosperity leads to tendency to give rise to self-expression values ... and ... self-expression values prove to be more strongly linked with democracy that any other factor" (Inglegart, Welzel 2005, pp. 4-5). Put another way, rather than a pre-determined one-way diffusion of values we found that our informants were responding to the enabling and facilitating ways in which church/state relations promoted sets of traditional family values and were also responding to the constraining ways in which the negatively perceived government/society cleavage characterized by disorder and bribery were impeding social and economic development and made desirable the selective transfer of "law and order" values.

Third, in finding little evidence of a state/church cleavage but much evidence of a government/society cleavage we argue that cleavages work in context-specific ways and entrench structural inequalities. In the case of Moldova, the receipt of financial remittances reduces the pressure on the government to undertake radical economic or political restructuring, or to actively court the diaspora to aggressively invest in the country. Furthermore, the gendering of migration, with women leaving Moldova to work in domestic employment overseas, provides a continuing migration safety valve that is broadly in line with traditional views of women's caring work. As above, the limited incidence of return migration or social remitting suggests this situation will persist. 
These results have implications for further research. Taken together, we believe our results suggest that an understanding of how values are changing under globalization should take account of the transnational elements of migrants' daily lives and the historic and geographic layers of structural conflicts and inequalities. Predicting shifts in values on the basis of historic precedence or geographic locality alone mis-specifies the role that context plays in social change which, as above, can be sometimes constraining and sometimes enabling. That said, we also note that, at least for the Moldovan-Czech system, the persistence of inequality seems likely, implying some limits to migrants' agency and to the migration-development nexus, and raising the issue of who or what is responsibile for broader social interventions that may reduce economic and social inequality.

\section{References}

ANDERSON, B. (2006): Imagined Communities. Verso, New York.

BAILEY, A.J. (2001): Turning Transnational: Notes on the Theorisation of International Migration. International Journal of Population Geography, 7, 413-428.

BOCCAGNI, P., DECIMO, F. (2013): Mapping Social Remittances. Migration Letters, 10, 1, 1-10.

CREWE, I. (1994): Voters, Parties and Leaders Years on Western Electoral Studies and the Democraties of Eastern Europe. In: Budge, J., McKay, D. (eds): Developing Democracy. SAGE, London, Thousand Oaks, New Delhi, 56-70.

DEMICKIJ, V. (2016): Moldavija možet stat' federacijej. Echo Planety, 17.

Charitonova, N. (2015): Pridněstrovskij konflikt (1988-2002). Linija-Grafik, Moskva.

DA VANZO, J., GRAMMICH, C.A. (2001): Dire Demographics: Population Trends in the Russian Federation (No. 1273). RAND corporation.

DE HAAS, H. (2010): Migration and Development: A Theoretical Perspective. International Migration Review, 44, 1, 227-264.

DICKINSON, J., BAILEY, A.J. (2007): (Re)membering Diaspora: Uneven Geographies of Indian Dual Citizenship. Political Geography, 26, 7, 757-774.

DRBOHLAV, D. (2011): Imigrace a integrace cizinců v Česku: Několik zastavení na cestě země v její migrační proměně z Davida na téměř Goliáše. Geografie, 116, 4, 401-421.

DUGOGLO, T., ONOFREJ, O. (2016): Ocenka demograficheskoj nestabilnosti v Respublike Moldova. Agrarnaja reforma ekonomika i pravo, 3, 9, 96-125.

European Values Study 2008 (ESV): Integrated Datase. GESIS Data Archive, Cologne.

Extended Migration (2012): Profil of Republic Moldova. International Organization for Migration. Mission to Moldova.

GCIM (2005): Migration in an Inter-connected World. Global Commission on International Migration (GCIM), United Nations, New York.

GRABOWSKA, I., ENGBERSEN, G. (2016): Social Remittances and the Impact of Temporary Migration on an EU Sending Country: The Case of Poland. Central and Eastern European Migration Review, 5, 2, 99-117.

GRABOWSKA, I., GARAPICH, M. (2016): Mapping Social Remittances and 'Segmented Development' in Central and Eastern Europe. Central and Eastern European Migration Review, $5,2,5-13$. 
HANNERZ, U. (1996): Transnational Connections. Routledge, London.

HLOUŠEK, V. (2002): Koncept konfliktních linií v západní politické vědě a jeho proměny. Politologický časopis, 4, 398-414.

INGLEHART, R. (1981): Post-Materialism in an Environment of Insecurity. American Political Science Review, 75, 4, 880-900.

INGLEHART, R., WELZEL, CH. (2005): Modernization, Cultural Change and Democracy, The Human Development Sequence. Cambridge University Press, Cambridge.

INGLEHART, R., WELZEL, CH. (2008): The Role of Ordinary People in Democratization. Journal of Democracy, 19, 1, 126-140.

INGLEHART, R., WELZEL, CH. (2010): Changing Mass Priorities: The Link between Modernization and Democracy. Perspectives on Politics, 8, 2, 551-567.

ISAAKYAN I., TRIANDAFYLLIDOU, A. (2016): Female High-skill Migration in the $21^{\text {st }}$ Century: The Challenge of the Recession. In: High-skill Migration and Recession. Palgrave Macmillan UK, 3-21.

KRZYŽOWSKI, L. (2016): Structuring Social Remittances: Transnational Networks of Polish Migrants. In: Europe in a Global Context. Palgrave Macmillan UK. 71-93.

LACROIX, T., LEVITT, P., VARI-LAVOISIER, I. (2016): Social Remittances and the Changing Transnational Political Landscape. Comparative Migration Studies, 20, 4, 1-5.

LEVITT, P. (1998): Social Remittances: Migration Driven Local-Level Forms of Cultural Diffusion. The International Migration Review, 32, 4, 926-948.

LEVITT, P. (2005): Social Remittances - Culture as a Development Tool. Presentation - International Forum on Remittances, http://services.iadb.org/wmsfiles/products/Publications/561717.pdf (1.9.2017).

LEVITT, P., LAMBA-NIEVES (2011): Social Remittances Revisited. Journal of Ethnic and Migration Studies, 37, 1, 1-22.

LEVITT, P., NYBERG-SORENSEN, N. (2004): The Transnational Turn in Migration Studies. Global Migration Perspectives, No. 6. Global Commission on International Migration, Geneva.

LIPSET, S.M., ROKKAN, S. (1967): Cleavage Structures Party Systems and Voters Aliguments. In: Lipset, Rokkan (eds.): Party Systems and Voters Aliguments: Cross - National Perspective. The Free Collier \& Mac Millan, New-York-London, 1-64.

LUPTÁK, M., LUPTÁKOVÁ, M. (2013): Mezinárodní migrace: pohledy a nadhledy. Červený Kostelec, Pavel Mervart.

LUPTÁKOVÁ, M. (2009): The Nature and Origin of Evil according to the Eastern Christian Church. In: Gilly, T., Gilinskiy, J., Sergein V.A., Thomas C.C., eds. (2009): The Ethics of Terrorism. Innovative Approaches from an International Perspective (17 lectures). LTD Springfield, Illinois, USA. 218-224.

Moldavsko - základní charakteristiky teritoria. http://www.businessinfo.cz/cs/clanky/moldavsko-zakladni-charakteristika-teritoria-19033.html (1.9.2017).

MOŠNJAGA V., LUPTÁK M. (2008): Česko v plánech a strategiích moldavských pracovních migrantů. In: Nelegální ekonomické aktivity migrantů (Česko v evropském kontextu). Karolinum, Praha, 203-208.

MOŠNJAGA, V. (2012): Cirkuljarnaja migracija naselenija Respubliky Moldova. Karim Vostok. Konsorcium př́kladných issledovanij po meždunarodnoj migracii, Kišinjov, 1-9.

MUKOMEL, P., PAIN, V., POPOV, A. (1999): Sojuz raspalsja - mežnacional'nyje konflikty ostalis. Nezavisimaja gazeta. (10.1.1999).

NOVIKOVA, O. (2015): Pridněstrovje: avtonomija ili nezavisimost'. In: Aktual'nye problémy Evropy. Sbornik naučných trudov. Alfa Plus, Moskva, 106-145. 
NOWICKA, M., ŠERBEDŽIJA, V. (2016): Migration and Social Remittances in a Global Europe. Europe in Global Context, Palgrave Macmillan.

PORTES, A. (1998): Social Capital: Its Origins and Applications in Modern Sociology. Annual Review of Sociology, 24, 1, 1-24.

RABUŠIC, L. (2000): Je česká společnost „postmaterialistická“? Sociologický časopis, 36, 1, 3-22. ROKKAN, S. (1999a): Mass Politics. In: Flora P., Kuhnle S., Urwin D. (eds). State Formation, National Building and Mass Politics in Europe. The Theory of Steine Rokkan. Oxford University Press, Oxford, 225-340.

ROKKAN, S. (1999b): State Formation and National Building. In: Flora, P., Kuhnle, S., Urwin, D. (eds.): State Formation National Building and Mass Politics in Europe. The Theory of Stein Rokkan. Oxford University Press, Oxford, 93-224.

RÖMELE, A. (1999): Cleavage Structurs and Party Systems in East and Central Europe. In: Lawson, K., Römele, A., Karasimeona, G. (eds.): Cleavages, Parties and Voters Studies from Bulgaria, the Czech Republic, Hungary, Poland and Romania. Westport, Praeger Publishers, $1-18$.

SANDU, D. (2010): Modernising Romanian Society through Temporary Work Abroad. In: Black, R., Engbersen, G., Okólski, M., Pantiru, C. (eds.): Continent Moving West? EU Enlargement and Labour Migration from Central and Eastern Europe. Amsterdam University Press, Amsterdam, 271-287.

SANDU, D. (2016): Remittances as Home Orientation Rooted in the Lifeworlds of Immigrants. Central and Eastern European Migration Review, 5, 2, 81-98.

SOLARI, C. (2010): Resource Drain vs. Constitutive Circularity: Comparing the Gendered Effects of Post-soviet Migration Patterns in Ukraine. Anthropology of East Europe Review, 28, 1, 215-238.

VAN HOUTUM, H. (2010): Human Blacklisting: The Global Apartheid of the EU's External Border Regime. Environment and Planning, 28, 6, 957-976.

VARI-LAVOISIER, I. (2016): The Economic Side of Social Remittances: How Money and Ideas Circulate between Paris, Dakar, and New York. Comparative Migration Studies, 20, 4, 1-34.

VANORE, M., SIEGEL, M. (2015): The Evolution of Gendered Migration Trajectories from Moldova \& Georgia. Comparative Migration Studies, 21, 3, 4.

VIANELLO, F.A. (2013): Ukrainian Migrant Women's Social Remittances: Contents and Effects on Families Left behind. Migration Letters, 10, 91-100.

WORLD BANK (2016): Migration and Remittances Factbook 2016. (Third edition). World Bank Group. Available at http://siteresources.worldbank.org/INTPROSPECTS/Resources/334934-1199807908806/4549025-1450455807487/Factbookpart1.pdf (31.5.2017)

\section{SHRNUTí}

\section{Hodnoty migrantů a sociální remitence v současném výzkumu vazeb mezi migrací a rozvojem (na příkladu Moldavanů v Česku)}

Cílem př́spěvku je nejenom stručně popsat a vysvětlit v odborné literatuře poměrně nový koncept sociálních remitencí, ale především tento koncept nově empiricky uchopit ve vazbě na úzce související hodnoty migrantů. Sociální remitence se zařazují k již tradičním tématům, analyzovaným při zkoumání důležitých vztahů mezi migrací a rozvojem, jimiž jsou zejména - finanční 
remitence, diaspory a únik mozko̊. Sociální remitence (chápeme v souladu s definicí Levitt 1998, s. 927) jako nově nabyté zkušenosti migrantů - „tok idejí, vzorců chování, identit a sociálního kapitálu z cílové země do prostředí země zdrojové..." (Levitt 1998, s. 927). Lze je dále dělit na normativní struktury, systémy praxe a sociální kapitál. Koncept sociálních remitencí má rozvojový a modernizační potenciál, je však zatím „mladý“, málo teoreticky i metodologicky rozvinutý, vnitřně velmi diverzifikovaný a zatížený především obtížnou operacionalizací mnoha proměnných reprezentujících sociální remitence. V Česku doposud tento koncept nebyl představen, ani nijak empiricky uchopen. Sociální remitence jsou v tomto příspěvku zkoumány na vzorku moldavských migrantů v Praze (a Pardubicích).

Konkrétní výsledky jsou diskutovány v perspektivě dvou teorií - sociologické dimenze teorie konfliktních (štěpících) linií (Lipset, Rokkan 1967) a teorie modernizace, vývoje od moderní/ materialistické k postmoderní/postmateriální společnosti (Inglehart, Welzel 2005). Interpretace je navázána na paradigma vztahů migrace a rozvoje. V analýze jsme vycházeli z předpokladu, že rozdílné hodnotové preference a postoje obyvatelstva i vzorce jejich chování odrážejí protikladné konfliktní zájmy zakořeněné v sociální struktuře společnosti. Lipset a Rokkan (1967) v této souvislosti vytvořili koncepci čtyř konfliktních linií: (a) centrum-periferie, (b) stát-církev, (c) město-venkov a (d) vlastnící-pracující, jež jsou charakteristické pro moderní industriální společnost. S nástupem postindustriální společnosti se tyto konflikty tlumí a modifikují a rozhodujícím se podle Ingleharta, Welzela (např. 2005) stává konflikt materiální versus postmateriální hodnoty. Obě tyto koncepce ve stávajícím článku jsou chápany jako klíčové pro sociálně-ekonomickou a politickou charakteristiku současné moldavské společnosti a míru její připravenosti přijmout inovační sociální remitence.

Výzkum sociálních remitencí moldavských migrantů v Česku má své opodstatnění. Mapuje migraci z Moldavska - z jedné z nejchudších zemí Evropy, kde stát absolutně neplní své funkce a především ekonomicky motivovaná migrace dominuje migrační motivaci a svoji intenzitou dlouhodobě dále destruuje zbylý rozvojový potenciál. V cílovém Česku, další postkomunistické zemi, která však poměrně úspěšně prošla hlubokou politickou a socioekonomickou transformací a stala se migračně atraktivní, hrají Moldavané důležitou roli zejména na tzv. sekundárním trhu práce.

S ohledem na charakter zdrojové migrační země - postsovětského Moldavska - jsme konkrétně testovali tři základní teze: (A) Migranti korigují a budují svůj hodnotový systém jako součást svého denního prožívání v transnacionálních sítích. (B) Migranti reálně i potenciálně přenášejí tyto hodnoty zpět do své mateřské země, přičemž podoba těchto hodnot materializovaná v sociálních remitencích je závislá na historickém a geografickém kontextu zdrojové země migrace, zejména na rozporech v klíčových konfliktních liniích společnosti. (C) Cirkulace a užití těchto hodnot vtělených do sociálních remitencí nejenom reaguje, ale také současně posiluje existující stav „tradičních“ konfliktních linií, tedy brzdí rozvoj a přispívá k rozdílům mezi zdrojovou a cílovou zemí.

Výzkum proběhl pomocí semi-strukturovaných interview mezi členy týmu Geomigrace a 28 moldavskými migranty v Praze a Pardubicích v období února až dubna 2017 (interview v ruském, českém nebo anglickém jazyce). Výběr byl organizován pomocí vlastních kontaktů, v součinnosti s postsovětskými, v Praze již déle usazenými prostředníky a pravoslavnou církví. Migranti museli mimo jiné v Česku pobývat déle než 6 měsíců a museli mít silné vazby na Moldavsko.

Při zjištování sociálních remitencí u daných migrantů vyšlo najevo, že informanti nové zkušenosti vnímají, reflektují, ale minimálně je akceptují a tedy i minimálně přenášejí zpět do Moldavska. (Mnoho se jich také odmítá vracet do své mateřské země.) Reálný a potenciální význam 
jejich sociálních remitencí pro rozvoj a modernizaci mateřské země je malý. To plyne zejména z povahy jejich „primárních“ hodnot a modelů chování i odvozeného vnímání a posuzování charakteru nového prostředí, kterému jsou vystaveni. Tedy nejde o prosté „kopírování nového modelu / přenos novoty“, ale o hodnocení nově získaného skrze neustálé porovnávání s dřívější zkušeností a vazbou na mateřskou moldavskou společnost. Jelikož ta byla v postsovětské éře výrazně poznamenána regresivními procesy sociální involuce od industriálně-agrární společnosti k agrární společnosti, upřednostňovali informanti ve svých odpovědích především materiální hodnoty, kterými disponuje česká společnost (výše finančního ohodnocení pracovníka, právní řád, systém zdravotní a sociální péče, fungování veřejné dopravy), jelikož jejich přenos by přispěl podle jejích mínění k překonání sociálně-ekonomické zaostalosti Moldavska a nefunkčnosti moldavského státu. Zaostalost je dána právě nedořešením řady problémů vyvěrajících z existujících konfliktních linií. Naopak hodnoty postmaterialismu, se kterými se v Česku take setkávají, jako více individualismu, touha po samostatnosti, svoboda volby, respekt k menšinám, širší politická participace se v odpovědích migrantů explicitně př́liš neobjevily (zdůrazňování významu emancipace žen v sovětském pojetí respondenty není postmateriální hodnota). V rozporu s obecně zjednodušujícím předpokladem, že pobyt migranta ve více postmaterialistickém prostředí bude pomocí sociálních remitencí dále reprodukovat postmaterialismus i v mateřské zemi se ukazuje, že naopak migrační zkušenost na příkladu Moldavska může spíše vést k upevnění stávajícího stavu. Důvod vidíme především v „bezproblémovém“ a důležitém vztahu v linii stát-církev, kdy silně věřící obyvatelstvo (včetně migrantů) nepůjde do konfliktu, aby rozbilo ekonomicky rozpadající se a pouze na principech korupce fungující stát. Posun v modernizaci a tedy i do fáze postmaterialistické a s tím související potenciální efektivní využití do Moldavska vstupujících četných a různorodých sociálních remitencí je možné očekávat až po vyřešení zásadních rozporů konfliktních linií včetně té, možná klíčové a dnes zdánlivě nekonfliktní - mezi státem a církví.

Článek uzavíráme voláním po dalších výzkumech hodnot migrantů, které by mohly dále přispět k vysvětlení existence a podmíněností nerovností mezi zdrojovými a cílovými zeměmi migrace v současné éře globalizace.

\section{ACKNOWLEDGEMENTS}

This study was supported by the Czech Science Foundation project: "Moldovans in Prague (Czechia) and Torino (Italy) - migratory and integration patterns, financial and social remittances under scrutiny" No. P404/16-22194S.

We thank all the informants for sharing with us their migratory experience. Moreover, big thanks go to Zdeněk Čermák, Eva Janská, Lenka Pavelková, Markéta Seidlová and Miroslav Košař who assisted us in making all interviews. 